\title{
Changes in Sensitivity to Acriflavine of Escherichia coli Grown in Media of Different Glucose Contents
}

\author{
By H. NAKAMURA \\ Biological Institute, Faculty of Science, Konan University, Kobe, Japan \\ (Accepted for publication I6 June 1967)
}

\begin{abstract}
SUMMARY
Organisms of Escherichia coli $\mathrm{K}-\mathrm{I} 2$ strains sensitive and resistant to acriflavine were plated on media with and without acriflavine after growth in media containing different concentrations of glucose. Proportionally more organisms produced colonies, in the presence of acriflavine, after growth in media containing a high concentration of glucose than in media with lower glucose contents. The final $\mathrm{pH}$ value of the growth medium was low with the high glucose media. With the resistant strain, the number of bacteria which survived acriflavine increased as the final $\mathrm{pH}$ value of the medium from which bacteria were harvested was decreased, but the initial glucose concentration rather than the final $\mathrm{pH}$ value of the culture was more influential in increasing survival with the sensitive strain. The acriflavine-binding capacity of the bacteria was affected by the initial glucose concentration of culture medium probably indirectly through a change of $\mathrm{pH}$. Acriflavine sensitivity of the bacteria varied with the amount of acriflavine bound. The acriflavinebinding capacity of bacteria modified by the $\mathrm{pH}$ value of culture medium was stabilized in the course of several doublings of bacteria in that medium. The glucose concentration of the medium affected the acriflavine sensitivity of the sensitive strain through some mechanism other than the change of $\mathrm{pH}$.
\end{abstract}

\section{INTRODUCTION}

In the studies on genetic control of acriflavine sensitivity of Escherichia coli $\mathrm{K}-\mathrm{I} 2$ it was found that the binding capacity of the bacteria for acriflavine and other basic dyes seemed to be controlled by a gene which controlled the acriflavine sensitivity and which lay in the vicinity of the marker for lactose utilization (Nakamura, 1966). A long period was needed for the acriflavine resistance to be expressed following introduction of the resistance gene into acriflavine-sensitive bacteria by mating (Nakamura, 1965). During these investigations it was observed that the acriflavine sensitivity of the bacteria was markedly affected by the initial glucose content of the medium in which the organisms had been grown. The present paper shows that this effect of glucose concentration was partly due to the change of $\mathrm{pH}$ value of the culture during growth, which in turn affected the acriflavine binding of the bacteria, and also that the $\mathrm{pH}$ shift was not the sole factor involved in the glucose concentration effect.

\section{METHODS}

Organisms. Two strains of Escherichia coli $\mathrm{K}-\mathrm{I} 2$ were used. One, I8/1042, is an acriflavine (AF)-sensitive strain, isolated as a spontaneous mutant from a wild-type AF-resistant female strain. The other, N90, is an AF-resistant female strain obtained 
by a cross of $\mathrm{I} 8 / 1042$ with an AF-resistant Hfr strain of Escherichia coli K-I2, strain W I895. The characters of these strains were described previously (Nakamura, I965).

Media. The strains were maintained in brain-heart infusion (Difco). For experiments, bacteria were grown overnight at $37^{\circ}$ in a liquid medium composed of (g./1.): Difco nutrient broth (solid), $8 ; \mathrm{NaCl}, 5$; glucose, $\mathrm{I}$; initially at $\mathrm{pH} 7 \cdot 4$. This medium will be referred to as standard broth. A stock solution of acriflavine was sterilized at $100^{\circ}$ for $20 \mathrm{~min}$. and stored in a refrigerator, for not more than Io days.

For solid media, powdered agar $(\mathrm{I} \cdot 5 \%$ ) was added. AF-broth agar was prepared by adding AF solution to the broth agar after it had cooled to $60-70^{\circ}$.

Determination of acriflavine content of bacteria. As negative-charge density of bacteria is reported to decline remarkably during the active growth phase (Abramson, Moper \& Gorin, 1942), bacteria in the stationary phase of a culture in broth were sampled and suspended in AF-media for the determination of AF-binding. The amount of bacteria to be suspended was turbidimetrically adjusted to be equivalent to about $700 \mu \mathrm{g}$. dry wt bacteria $/ \mathrm{ml}$. Samples taken from AF-media, after a varying period of time specified later, were centrifuged $(14,500 \mathrm{~g})$ for $5 \mathrm{~min}$. at $5^{\circ}$, and the dye concentration in the supernatant fluid determined spectrophotometrically at $450 \mathrm{~m} \mu$. The amount of AF lost from the supernatant fluid was taken as the AF-content of the bacteria and used as an index of their dye-binding capacity. Although the medium itself was coloured yellowish, the absorption spectrum of AF could be differentiated when the medium was diluted a few times; medium without dye used as reference.

Determination of $p H$ value in culture media. A sample of the culture was centrifuged $(\mathrm{I} 4,500 \mathrm{~g})$ for $5 \mathrm{~min}$. at $5^{\circ}$, and $\mathrm{pH}$ value of the supernatant fluid determined electrometrically.

Thus the experiments done took the following form: organisms were grown in various liquid media; after a given time the organisms were harvested and tested for their degree of survival in AF-media (by plating on AF-nutrient agar) and for AFbinding capacity; the $\mathrm{pH}$ value of the culture fluids at the time of harvesting was measured.

\section{RESULTS}

\section{Glucose content of medium and AF-sensitivity of bacteria}

Strains N90 (AF-resistant) and I8/1042 (AF-sensitive) were inoculated in broth media which contained glucose in concentrations ranging from 0.05 to $6.4 \mathrm{~g}$. $/ 1$. After overnight incubation at $37^{\circ}$, a part of each culture was diluted by a factor of $6 \times 10^{6}$ and plated on broth agar containing $\mathrm{AF}, 250 \mu \mathrm{g} . / \mathrm{ml}$., for resistant strain $\mathrm{N} 90$ and I $\mu \mathrm{g} . / \mathrm{ml}$. for sensitive strain I8/1042, and on broth agar alone, as a control. Colony counts on AF-agar are expressed as $\%$ of those on the control plates; this gave a measure of the sensitivity (\% survival) to acriflavine of the harvested organisms.

The rest of each culture was centrifuged and the $\mathrm{pH}$ value of the supernatant fluid determined.

Figure I represents \% survivals of the two strains on the AF-agar plates and the final $\mathrm{pH}$ values of the media from which the bacteria had been harvested. The $\%$ survival was high when culture medium originally contained high concentrations of glucose. The \% survival on AF-agar of strain $\mathrm{N} 90$ was related to the $\mathrm{pH}$ value of the 
culture at the time of harvesting, but with strain $\mathrm{I} 8 / 1042$ the initial glucose concentration rather than the final $\mathrm{pH}$ value of the culture showed a better correlation with $\%$ survival on AF-agar.

\section{Effect of initial glucose concentration in buffered media}

To examine the effect of initial glucose concentration in cultures kept at a relatively constant $\mathrm{pH}$ value, broth medium was supplemented with phosphate buffer $(\mathrm{pH}$ $7.05 ; \mathrm{M} / \mathrm{I} 5$ final concentration). The initial glucose concentrations were from 0.05 to $3.2 \mathrm{~g}$./1. After growing strains $\mathrm{N} 9 \mathrm{O}$ and $\mathrm{I} 8 / \mathrm{IO} 2 \mathrm{2}$ in the media overnight, samples from the cultures were diluted and plated on AF-broth agar containing $250 \mu \mathrm{g} . / \mathrm{ml}$. and I $\mu \mathrm{g}$. $/ \mathrm{ml}$. of AF, respectively. Figure 2 shows that the $\%$ survival of strain 90 in the presence of $\mathrm{AF}$ remained unchanged as long as the $\mathrm{pH}$ value of the culture did not change, namely with initial glucose concentrations up to $\mathrm{I} \cdot 6 \mathrm{~g}$./1. With strain $\mathrm{I} 8 / \mathrm{I042}$, in contrast, the \% survival increased even when the $\mathrm{pH}$ value remained constant. Hence, the initial glucose concentration of the culture medium influenced the AFsensitivity of bacteria through final $\mathrm{pH}$ value in the former case and not through $\mathrm{pH}$ value in the latter case.

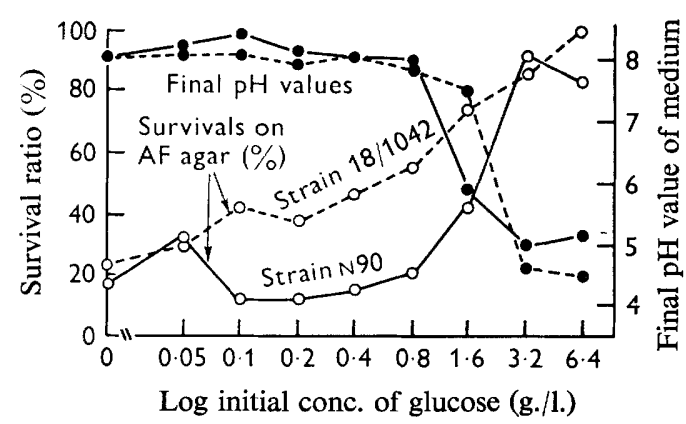

Fig. I

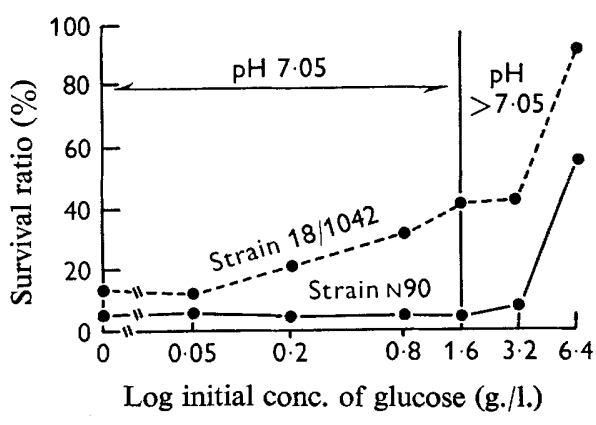

Fig. 2

Fig. II. Effect of initial glucose concentration in culture medium on acriflavine (AF) sensitivity of Escherichia coli $\mathrm{K} 12$ AF-sensitive strain I8/1042 and AF-resistant strain N90. Bacteria were inoculated into broth media of graded glucose contents and, after overnight incubation at $37^{\circ}$, dilutions $\left(\mathrm{I} / 6 \times 10^{6}\right)$ of cultures were plated on AF-containing broth agars. The $\mathrm{pH}$ values of the cultures at time of sampling were determined after centrifugation. - - -, Strain $18 / 1042$; - strain N90; O survival ratio on broth agar containing $\mathrm{I} \mu \mathrm{g}$. AF/ml. for strain $\mathrm{I} 8 / 1042$ and $250 \mu \mathrm{g}$. AF/ml. for strain $\mathrm{N} 90$;, , Final pH value of medium.

Fig. 2. Effect of initial glucose concentration of broth medium buffered at $\mathrm{pH} 7.05$ by phosphates on the AF-sensitivity of Escherichia coli KI2. AF-sensitive strain $18 / 1042$ and AF-resistant strain N90. Organisms were inoculated into broth medium of graded glucose concentrations buffered at $\mathrm{pH} 7.05$ by phosphates. After overnight incubation at $37^{\circ}$, dilutions $\left(1 / 6 \times 10^{6}\right)$ of cultures were plated on AF-containing broth agars.,$--- \%$ survival of strain $18 / 1042$ on $\mathrm{I} \mu \mathrm{g}$. AF/ml. broth agar; -, \% survival of strain $\mathrm{N} 90$ on $250 \mu \mathrm{g}$. AF $/ \mathrm{ml}$. broth agar.

\section{Acriflavine binding capacity and $\mathrm{pH}$ value of medium}

It is known that bacteria of the AF-sensitive strain I8/1042 bind more AF than do bacteria of the AF-resistant strain N90 (Nakamura, I966). In connexion with the effects of initial glucose concentration and the $\mathrm{pH}$ value of the medium at harvest, on the AF-sensitivity of the bacteria, the effects of these factors on the AF-binding capacity of bacteria are interesting. Bacteria of the two strains were grown overnight 
in broth media adjusted initially to $\mathrm{pH} 5 \cdot 4,6 \cdot 2,7 \cdot 2$ and $8 \cdot 0$ by $\mathrm{M} / 15$ phosphate buffer. The bacteria were then harvested, washed 3 times with $0.85 \%(\mathrm{w} / \mathrm{v}) \mathrm{NaCl}$ solution, and suspended in a broth medium containing $5 \mu \mathrm{g} \mathrm{AF} / \mathrm{ml}$. After incubation for $60 \mathrm{~min}$. at $37^{\circ}$, the AF-binding capacity of these bacteria was determined. The binding capacity of either strain increased with increase of initial $\mathrm{pH}$ value of the culture medium, as shown in Fig. $3 \mathrm{~A}$. When bacteria grown in the standard broth without phosphate buffer were directly transferred into AF-containing broth media of various $\mathrm{pH}$ values, the AF-binding of the bacteria increased with increase of $\mathrm{pH}$ value (Fig. $3 \mathrm{~B}$ ). Thus, $\mathrm{pH}$ value of the preceding culture medium and $\mathrm{pH}$ value of the AF-medium were both effective on the AF-binding of the bacteria. Since the AF-sensitivity was lower at low $\mathrm{pH}$ values (Fig. I, 2), the effect of $\mathrm{pH}$ value on sensitivity was the inverse of the effect on AF-binding in both strains.

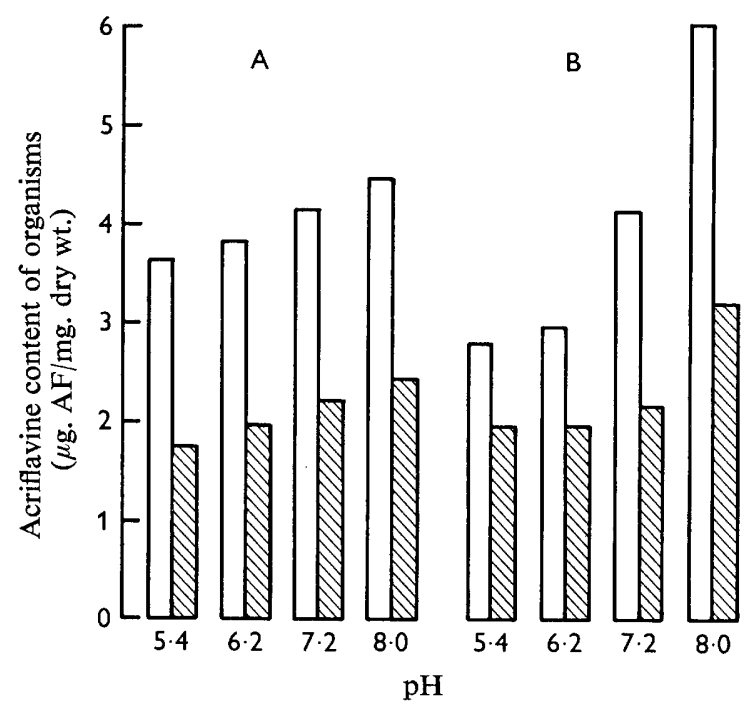

Fig. 3. Effect of $\mathrm{pH}$ value on AF-binding by Escherichia coli $\mathrm{K}$ I 2 AF-sensitive strain $\mathrm{I} 8 / \mathrm{I} 042$ and AF-resistant strain N90. A, strain N90 (shaded) and 18/1042 (unshaded) were grown overnight in broth media of initial $\mathrm{pH}$ values indicated, harvested, well washed and then incubated for $60 \mathrm{~min}$. in the broth containing $5 \mu \mathrm{g}$. AF $/ \mathrm{ml}$. for measurement of AF-binding. $\mathrm{B}$, Organisms of $\mathrm{N} 90$ (shaded) and $\mathrm{r} 8 / 1042$ (unshaded) grown in the standard broth were directly suspended in AF-broth $(5 \mu \mathrm{g} . / \mathrm{ml}$.), buffered at the indicated $\mathrm{pH}$ values, and then incubated for $20 \mathrm{~min}$. for determination of AF-binding.

Since the AF-sensitivity of I8/1042 organisms decreased as initial glucose concentration of the medium increased even at the same $\mathrm{pH}$ value (Fig. I, 2), the effect of initial glucose concentration on AF-binding capacity was examined by using buffered culture media. Organisms of strains N90 and I8/1042 were grown in broth media containing different concentrations of glucose and adjusted to $\mathrm{pH} 7 \cdot 4$ by phosphate buffer. After overnight incubation, the bacteria were harvested and washed and their AF-binding capacities determined by suspension in AF-containing broth. Table I shows that for both strains the AF-binding varied with the $\mathrm{pH}$ value rather than by the initial glucose concentration. 
Table I. Effect of glucose concentration of buffered medium on acriflavine $(A F)$-binding capacity of Escherichia coli $K-12$ AF-sensitive strain $I 8 / 1042$ and AF-resistant strain N9O

Organisms were inoculated in media buffered at $\mathrm{pH} 7 \cdot 4$ and containing graded initial concentrations of glucose and incubated overnight. The organisms were then harvested, well washed, and then incubated for $60 \mathrm{~min}$. in broth containing $5 \mu \mathrm{g} \mathrm{AF} / \mathrm{ml}$.

Initial glucose concentration in culture medium (g./1.)

\begin{tabular}{|c|c|c|c|c|c|c|c|}
\hline \multirow[t]{2}{*}{ Strain } & o & 0.05 & 0.20 & 0.80 & $I \cdot 60$ & $3 \cdot 20$ & $6 \cdot 40$ \\
\hline & \multicolumn{7}{|c|}{ Final $\mathrm{pH}$ value of culture } \\
\hline \multirow{3}{*}{$\begin{array}{l}18 / 1042 \\
\text { N9O }\end{array}$} & $7 \cdot 31$ & $7 \cdot 32$ & $7 \cdot 29$ & $7 \cdot 19$ & $7 \cdot 18$ & 6.91 & $5 \cdot 80$ \\
\hline & $7 \cdot 41$ & $7 \cdot 38$ & $7 \cdot 36$ & $7 \cdot 33$ & $7 \cdot 20$ & 7.05 & $6 \cdot 17$ \\
\hline & \multicolumn{7}{|c|}{$\begin{array}{c}\text { AF-content of organisms after treatment } \\
(\mu \mathrm{g} \mathrm{AF} / \mathrm{mg} \text {. dry wt) }\end{array}$} \\
\hline $18 / 1042$ & $4 \cdot 3 \mathrm{I}$ & $4 \cdot 12$ & $3 \cdot 88$ & 4 & 3.88 & 3. & $3 \cdot 16$ \\
\hline N90 & $2 \cdot 44$ & $2 \cdot 44$ & 2.53 & $2 \cdot 60$ & $2 \cdot 55$ & $2 \cdot 38$ & $\mathbf{I} \cdot 90$ \\
\hline
\end{tabular}

Table 2. The need for multiplication for modification of acriflavine $(A F)$ binding capacity by the $\mathrm{pH}$ value of the culture medium

Strains $18 / 1042$ and $N 90$ were inoculated with the indicated inoculum sizes into broth media adjusted to $\mathrm{pH} 6.0$ and $\mathrm{pH} 8.0$ and, after overnight incubation at $37^{\circ}$, organisms were well washed and suspended for $60 \mathrm{~min}$. in broth at $\mathrm{pH} 7 \cdot 4$ containing $5 \mu \mathrm{g}$. AF/ml.

\begin{tabular}{|c|c|c|c|c|}
\hline Strain & $\begin{array}{l}\mathrm{pH} \text { of } \\
\text { culture } \\
\text { medium }\end{array}$ & $\begin{array}{l}\text { Inoculum } \\
\text { size } \\
\text { (cells/ml.) }\end{array}$ & Doublings & $\begin{array}{l}\text { AF-content } \\
(\mu \mathrm{g} . \mathrm{AF} / \\
\text { mg. DW) }\end{array}$ \\
\hline $18 / 1042$ & & & & \\
\hline a & $\begin{array}{l}6 \cdot 0 \\
8 \cdot 0\end{array}$ & $\begin{array}{l}9.1 \times 10^{8} \\
9.0 \times 10^{8}\end{array}$ & $\begin{array}{l}2 \cdot 2 \\
1 \cdot 2\end{array}$ & $\begin{array}{l}3 \cdot 44 \\
3 \cdot 48\end{array}$ \\
\hline $\mathrm{b}$ & $\begin{array}{l}6 \cdot 0 \\
8 \cdot 0\end{array}$ & $\begin{array}{l}9.6 \times 10^{7} \\
8.7 \times 10^{7}\end{array}$ & $\begin{array}{l}5 \cdot 7 \\
4 \cdot 2\end{array}$ & $\begin{array}{l}3 \cdot 47 \\
3 \cdot 88\end{array}$ \\
\hline c & $\begin{array}{l}6 \cdot 0 \\
8 \cdot 0\end{array}$ & $\begin{array}{l}9.3 \times 10^{6} \\
8.1 \times 10^{6}\end{array}$ & $\begin{array}{l}8 \cdot 6 \\
7 \cdot 6\end{array}$ & $\begin{array}{l}3 \cdot 44 \\
3 \cdot 80\end{array}$ \\
\hline $\mathrm{d}$ & $\begin{array}{l}6 \cdot 0 \\
8 \cdot 0\end{array}$ & $\begin{array}{l}8.9 \times 10^{5} \\
9 \cdot 3 \times 10^{5}\end{array}$ & $\begin{array}{l}\text { II } 9 \\
\text { II } \cdot 0\end{array}$ & $\begin{array}{l}3 \cdot 44 \\
3 \cdot 85\end{array}$ \\
\hline $\mathrm{e}$ & $\begin{array}{l}6 \cdot 0 \\
8 \cdot 0\end{array}$ & $\begin{array}{l}9^{\cdot} 8 \times 10^{4} \\
9^{.} 8 \times 10^{4}\end{array}$ & $\begin{array}{l}15 \cdot 0 \\
14 \cdot 2\end{array}$ & $\begin{array}{l}3 \cdot 44 \\
3 \cdot 85\end{array}$ \\
\hline f & $\begin{array}{l}6 \cdot 0 \\
8 \cdot 0\end{array}$ & $\begin{array}{l}9 \cdot 5 \times 10^{3} \\
9 \cdot 5 \times 10^{3}\end{array}$ & $\begin{array}{l}18 \cdot 5 \\
17.8\end{array}$ & $\begin{array}{l}3 \cdot 44 \\
3 \cdot 90\end{array}$ \\
\hline $\begin{array}{c}\text { N9O } \\
\text { a }\end{array}$ & $\begin{array}{l}6 \cdot 0 \\
8 \cdot 0\end{array}$ & $\begin{array}{l}9.9 \times 10^{8} \\
1 \cdot 1 \times 10^{9}\end{array}$ & $\begin{array}{l}I \cdot 4 \\
I \cdot 0\end{array}$ & $\begin{array}{l}I \cdot 8 \mathbf{i} \\
I \cdot 73\end{array}$ \\
\hline b & $\begin{array}{l}6 \cdot 0 \\
8 \cdot 0\end{array}$ & $\begin{array}{l}1 \cdot 1 \times 10^{8} \\
7 \cdot 8 \times 10^{7}\end{array}$ & $\begin{array}{l}5 \cdot 0 \\
4.8\end{array}$ & $\begin{array}{l}I \cdot 8 I \\
2 \cdot 08\end{array}$ \\
\hline c & $\begin{array}{l}6 \cdot 0 \\
8 \cdot 0\end{array}$ & $\begin{array}{l}9.6 \times 10^{6} \\
1 \cdot 1 \times 10^{7}\end{array}$ & $\begin{array}{l}8 \cdot 2 \\
7 \cdot 5\end{array}$ & $\begin{array}{l}I \cdot 78 \\
2 \cdot 08\end{array}$ \\
\hline d & $\begin{array}{l}6 \cdot 0 \\
8 \cdot 0\end{array}$ & $\begin{array}{l}9.6 \times 10^{5} \\
8.6 \times 10^{5}\end{array}$ & $\begin{array}{l}\text { II } \cdot 5 \\
\text { II } \cdot \text { I }\end{array}$ & $\begin{array}{l}I \cdot 8 I \\
2 \cdot 13\end{array}$ \\
\hline e & $\begin{array}{l}6 \cdot 0 \\
8 \cdot 0\end{array}$ & $\begin{array}{l}1.0 \times 10^{5} \\
9.9 \times 10^{4}\end{array}$ & $\begin{array}{l}14 \cdot 7 \\
14 \cdot I\end{array}$ & $\begin{array}{l}I \cdot 8 \mathrm{I} \\
2 \cdot \mathrm{I} 2\end{array}$ \\
\hline $\mathrm{f}$ & $\begin{array}{l}6 \cdot 0 \\
8 \cdot 0\end{array}$ & $\begin{array}{l}\mathrm{I} \cdot \mathrm{I} \times \mathrm{IO}^{4} \\
\mathrm{I} \cdot \mathrm{O} \times \mathrm{IO}^{4}\end{array}$ & $\begin{array}{l}17.9 \\
17.3\end{array}$ & $\begin{array}{l}I \cdot 82 \\
2 \cdot 12\end{array}$ \\
\hline
\end{tabular}


Modification of acriflavine-binding capacity and multiplication of the organisms

The AF-binding capacity of the bacteria was controlled not only by $\mathrm{pH}$ value of the AF-containing solution (Fig. 3 B), but also by the $\mathrm{pH}$ of the medium in which they had been grown (Fig. $3 \mathrm{~A}$ ). The following experiment was designed to see whether growth in the medium was necessary for $\mathrm{pH}$ value of the medium to modify AF-binding capacity of the organisms.

Freshly grown organisms of strains $\mathrm{N} 90$ and $18 / 1042$ were washed with saline and inoculated into broth media adjusted to $\mathrm{pH} 6 \cdot 0$ and $8 \cdot 0$, the inoculum sizes being graded as shown in Table 2. After overnight incubation at $37^{\circ}$, the bacteria were washed with saline and suspended in broth containing $5 \mu \mathrm{g}$. AF $/ \mathrm{ml}$. The AF-content of the bacteria after incubation for $60 \mathrm{~min}$. is represented in Table 2. The $\mathrm{pH}$ value of the incubation did not affect the AF-binding when bacteria underwent only one or two doublings in that medium.

\section{DISCUSSION}

It is known that the surface of bacteria bears a negative charge under physiological conditions, mainly because of the Donnan equilibrium and the ionization of surface components. Albert (I95I) showed that the positive ionization of acridine dyes is an important factor for their antibacterial action, and that an equilibrium between dye and bacteria is rapidly established. Hence, it may be considered that acriflavine (and other basic dyes) binds primarily with negatively charged sites on and near the cytoplasmic membrane, where acriflavine-sensitive metabolic machinery may be located.

It was shown by the experiments described above that the initial glucose concentration of the medium markedly affected the AF-sensitivity of the organisms grown in it, even after they had been well washed. And in the AF-resistant strain N90 a positive correlation was observed between the AF-sensitivity of organisms and the $\mathrm{pH}$ value of the medium from which they had been harvested. Three metabolic processes can operate to shift the $\mathrm{pH}$ value of culture medium used: (I) unbalanced uptake and output of anions and cations; (2) formation of basic substances from nitrogenous compounds; (3) formation of acids from neutral metabolites. The $\mathrm{pH}$ decrease observed with the high glucose media was probably due to the third factor.

The AF-binding capacity of organisms was markedly affected by $\mathrm{pH}$ value of the medium in which they had been grown, much acriflavine being bound by organisms from high $\mathrm{pH}$ media (Fig. $3 \mathrm{~A}$ ). This suggests a possible explanation for the observation that the organisms from high $\mathrm{pH}$ cultures were more sensitive to acriflavine than were those from low pH cultures. Thus, in the case of the AF-resistant strain (N90), and partly in the case of the AF-sensitive strain (18/1042), the effect of initial glucose concentration on the AF-sensitivity of the grown organisms might be accounted for by modification of the AF-binding capacity of organisms because of the $\mathrm{pH}$ shift of the culture to more acid values.

The AF-binding increased when the organisms were simply treated with acriflavine at an increased $\mathrm{pH}$ value (Fig. ${ }_{3} \mathrm{~B}$ ) and thus it might appear that, in the experiments illustrated in Fig. $3 \mathrm{~A}$, growth at a given $\mathrm{pH}$ value might not have been necessary to produce the effect of $\mathrm{pH}$ on subsequent AF-binding after washing of the organisms. However, this effect of $\mathrm{pH}$, prior to washing of the organisms and exposure to acriflavine, on the binding of acriflavine was lost when the organisms were not permitted 
to multiply at all (unpublished data) or to undergo more than two doublings at a given $\mathrm{pH}$ (Table 2). When the organisms were allowed to multiply by a factor more than two or so in a buffered broth medium, the AF-binding capacity characteristic of the $\mathrm{pH}$ value of the buffered broth medium in which the organisms were grown was retained even after washing. It is assumed that, when the organisms grew in media of different $\mathrm{pH}$ values, irreversible modification corresponding to the $\mathrm{pH}$ value occurred in the nature and amount of AF-binding sites.

The present results also show that a large initial glucose concentration increased the AF-tolerance of the AF-sensitive strain (18/1042) even when the $\mathrm{pH}$ value of the medium did not change. In the buffered medium the AF-binding capacity of the organisms did not change according to the initial glucose concentration (Table I). Hence the initial glucose concentration of the culture medium influenced the AFtolerance of the AF-sensitive strain not through changes in the AF-binding sites. There may possibly be a second process connecting glucose concentration and modification of AF-sensitivity in the AF-sensitive strain. In both of the strains the degree of binding of acriflavine by cells is affected by the $\mathrm{pH}$ value of medium but not by the glucose concentration directly.

The author thanks Professor J. Ashida of Kyoto University for his interest in this work.

\section{REFERENCES}

Abaramson, H. A., Moper, L. S. \& Gorin, M. H. (1942). Electrophoresis of Proteins and The Chemistry of Cell Surfaces. New York: Reinhold Publishing Corp.

Albert, A. (1951). Selective Toxicity. London: Methuen and Co. Ltd.

NAKAMURA, H. (1965). Gene-controlled resistance to acriflavine and other basic dyes in Escherichia coli. J. Bact. 9o, 8.

Nakamura, H. (1966). Acriflavine-binding capacity of Escherichia coli in relation to acriflavine sensitivity and metabolic activity. J. Bact. 92, 1447.

\section{ADDENDUM}

After submission of this paper the author received a preprint from Dr S. Silver. They include the same experimental results as in this paper with respect to the effect of $\mathrm{pH}$ of acriflavine solution on the acriflavine uptake of Escherichia coli. SILVER, S., Levine, E., \& SpIelman, P. M. Acridine binding by Escherichia coli: pH dependency and strain differences. Submitted to $J$. Bact. 